\title{
Profiling for sustainable tourism: young travellers' self- transcendence values and motivations
}

\author{
Elena Cavagnaro ${ }^{1 *}$, Simona Staffieri ${ }^{2}$, Angelo Carrieri³ ${ }^{3}$ Kevin Burns ${ }^{4}$, \\ Nan Chen 5 and Alessandra Fermani ${ }^{6}$
}

\footnotetext{
${ }^{1}$ Academy of International Hospitality Research, Stenden Hotel Management School, NHL Stenden University of Applied Sciences, Leeuwarden, The Netherlands. E-mail: elena.cavagnaro@nhlstenden.com

${ }^{2}$ Department of European, American and Intercultural Studies, University of Rome La Sapienza, Italy

3 Department of Educational Sciences, Cultural Heritage and Tourism, University of Macerata, Italy

4 Department of Hospitality Management, Dundalk Institute of Technology, Ireland

5 School of Hotel and Tourism Management, The Hong Kong Polytechnic University, Hong Kong, China

${ }^{6}$ Department of Educational Sciences, Cultural Heritage and Tourism, University of Macerata, Italy

* Corresponding author
}

\begin{abstract}
Young people seek meaningful, participative, and co-created experiences. Yet young tourists seem less attracted than expected by tourism offers that emphasise involvement, such as sustainable tourism. A possible explanation lies in values and travel motivations specific to young travellers. Although travel motivations have been extensively researched, few have attempted to categorize the resulting list of travel motivations. Research on values is systematized but has limited predictive power because it is generally conducted without reference to immediate causes of behaviour such as motivations. This study proposes to segment young travellers using values and motivations simultaneously and, to account for socio-economic conditions, to investigate young travellers in China and Italy. Multivariate analysis revealed clusters that offer strong opportunities for a sustainable tourism proposition both in the Italian and the Chinese sample. Out of the other identified clusters, some offer similar opportunities yet require a different framing of the tourism offer, while some seem only interested in hedonic experiences. How this more sophisticated picture of young tourists may account for their tepidity towards sustainable tourism is discussed, alongside limitations, suggestions for future research, and a reflection about the re-start of European tourism after the COVID-19 pandemic.
\end{abstract}

Keywords: Youth tourism, sustainable tourism, youth tourism segment, Chinese culture, Italian culture, after COVID-19 tourism

Citation: Cavagnaro, E., Staffieri, S., Carrieri, A., Burns, K., Chen, N. and Fermani, A. (2021). Profiling for sustainable tourism: young travellers' self-transcendence values and motivations. European Journal of Tourism Research 28, 2810. 


\section{Introduction}

Although there is a growing need for meaningful experiences (Davis, 2016) particularly among young tourists (Vaux Halliday \& Astafyeva, 2014), tourism offers that emphasise involvement and depth such as sustainable tourism, still suffer from a lack of demand (Buckley, 2012). Sustainable tourism implies a genuine interest in experiencing and learning about the natural landscape and the hosting community based upon a personal commitment to support and protect both the cultural and natural heritage of the visited site (Canavan, 2017). To explain youngsters' unresponsiveness to sustainable tourism, literature mainly refers to values and motivations. Values are guiding principles in life and strongly though indirectly influence people's choices (Schwartz, 1994). The literature on pro-environmental behaviour suggests that self-transcendence values, such as helpfulness, encourage sustainable choices, while self-enhancing values, such as hedonism, mostly discourage them (De Groot \& Steg, 2008). Narcissism, moreover, strengthen self-enhancing values, while weakening self-transcendence ones (Naderi \& Strutton, 2014). Although the risk of oversimplifying is present, the observed prevalence of narcissistic values among youngsters has been proposed as the reason for their tepidity towards sustainable tourism (Canavan, 2017; UNWTO, 2016). Unlike values, motivation is a proximate antecedent of human action and has been studied extensively also by tourism scholars (Gillison et al., 2019). This literature reveals that travel motivation is a multidimensional phenomenon, that young adults' personality is not fully formed, and that therefore their travel motivations are difficult to grasp (Arnett, 2006; Richards, 2015). Consequently, young travellers are considered a mystery that still needs to be explored (Valentine \& Powers, 2013).

To help solve this mystery, further investigation on youngsters' values and travel motivations is mandatory. More specifically, when narcissistic values are called upon to explain youngsters' disinterest for sustainable tourism (e.g., Zografos \& Allcroft, 2007), limited emphasis is placed on travel motivations. Yet, to retain their predictive power, values should be considered simultaneously with more proximate antecedents of behaviour such as motivations (Stern, Dietz \& Guagnano, 1995). Moreover, while research on values is highly systematized, research on travel motivations is not (Fodness, 1994). Therefore, before connecting values to motivations, the long, inconsistent lists of travel motivations derived from existing literature should be first reduced to fewer consistent underlying components. Considering the influence of socio-cultural, economic, and political systems on both values and motivations, a cross-cultural approach should be adopted (Beugelsdijk \& Welzel, 2018). Finally, to avoid selection bias, research should look beyond those youngsters who have already manifested an interest or are actually engaged in a form of sustainable tourism (Cavagnaro, Staffieri \& Postma, 2018). Therefore, the aim of the current study is to profile young tourists from two countries (Italy and China) that widely differ in the politic and socio-economic systems, simultaneously using both remote (i.e. values) and proximate (i.e. motivations) antecedents of travel demand to evaluate youngsters' readiness to embrace a sustainable tourism offer. In the process, existing lists of travel motivations will be reduced to few underlying components.

The research is structured as follows. After a brief justification of the study's theoretical background, the literature on value orientations, travel motivations, and Italy's and China's socio-economic context is reviewed. A paragraph on the research's aim and questions introduces the research method section. Here the sample and respondents are described, the data collection procedure is explained, the scales used to measure value orientations and motivations are presented, and the choice for a quantitative study based on descriptive, multivariate, and cluster analysis is justified. Subsequently, a set of original findings is presented and discussed. In reflecting on these findings, suggestions are shared on how to best promote sustainable tourism to the different clusters. The study concludes with an overview of the 
theoretical and practical implications of the findings, including a reflection about post-COVID tourism in Europe, and with suggestions for further research.

\section{Theoretical Background}

Before reviewing the existing literature, the theoretical framework underlying this research is briefly presented. This study conceptualizes the demand for sustainable tourism as a behavioural choice for a pro-environmental and pro-social (in short: sustainable) offer. The antecedents of sustainable behaviour have been incorporated by Stern et al. (1995) in the causal model of environmental concern. The least mutable and most influential antecedent is an individual's position in the social structure. Social structures, such as the country where people live, shape behaviour through institutional constraints and incentives. This is the main reason this study focuses on two countries that widely differ in their institutional systems, such as China and Italy (Beugelsdijk \& Welzel, 2018). The next antecedent of sustainable behaviour in the causal model, values, are formed early in life, and have strong explanatory power on behavioural choices (Schwartz, 1994). Indeed, several studies have segmented tourists on the basis of their values (e.g., Kim, Borges \& Chon, 2006; Zografos \& Allcroft, 2007). Yet, the causal chain leading to behaviour does not stop with values. Values are "causally antecedent to more specific beliefs, which in turn are antecedent to [...] other proximate causes of particular actions" (Stern et al., 1995, p. 726). Therefore, to retain their strong predictive power, values should be considered simultaneously with more proximate antecedents of behaviour, such as motivation. Motivations are widely described in the literature as a proximate cause of a particular action (Fodness, 1994; Gillison et al., 2019). Consequently, this study considers both values and motivations in examining young travellers.

\section{Value Orientations}

In his seminal study on values as guiding principles in people's life, Schwartz (1994) distinguishes the values that reflect a concern with a person's interest (self-enhancement values) from the values that reflect a concern with collective interests (self-transcendence values). Environmental psychologists have adopted this distinction to explain pro-environmental and pro-social (i.e. sustainable) behaviour (Perkins \& Brown, 2012; Stern et al., 1995). Notably, the relative salience to individuals of sets of related values, so-called value orientations, predicts behaviour better than the study of single values (Perkins \& Brown, 2012). More specifically, individuals act sustainably to improve their feelings (hedonic value orientation); to increase personal resources and boost their status (egoistic value orientation); to act accordingly to normative goals such as helping others (altruistic value orientation) and protecting the environment (biospheric value orientation). While all value orientations may prompt sustainable behaviour, empirical evidence suggests that the hedonic and egoistic value orientations mostly influence a sustainable choice negatively (De Groot \& Steg, 20o8) or are too fickle to sustain it on the long run (Steg, Perlaviciute, Van der Werff \& Lurvink, 2014). Yet, hedonic values are strongly linked to a leisurely experience such as travelling (Kim, Ritchie \& McCormick., 2012), and enhancing egoistic values (such as status) may be a reason for travelling sustainably (Wheeller, 2005). Self-transcendence values, on the contrary, generally positively influence sustainable behaviour. However, while an altruistic value orientation reflects a concern for other human beings, a biospheric value orientation reveals a concern for nature for its own sake, i.e. without a direct reference to humans' welfare (De Groot \& Steg, 2008; Perkins \& Brown, 2012). Therefore, this study adopts Steg et al. (2014)'s four value orientations (egoistic, hedonic, altruistic, and biospheric) as antecedents of people's sustainable behaviour (Table 1).

While scholars agree that younger generations hold considerably different values than older ones (Glover, 2010; Valentine \& Powers, 2013), they disagree about which values they hold (Benckendorff \& 
Moscardo, 2010; Vermeersch, Sanders \& Willson, 2016). Several studies suggest that youngsters cherish materialistic and narcissistic values to a higher degree than older people (e.g., Lo, McKercher, Lo, Cheung, \& Law, 2011; Twenge \& Foster, 2010). However, other studies claim that youngsters are supportive of socially responsible companies (Furlow, 2011) and concerned with social and environmental issues (Moscardo, Murphy \& Benckendorff, 2011). Indeed, to paraphrase Valentine and Powers (2013), youngsters' value orientation is an enigma still waiting to be solved.

Value orientations have also been discussed by tourism scholars. Many studies, however, do not offer empirical evidence (e.g. Zografos \& Allcroft, 2007). Among empirical studies, some have not specifically targeted young tourists (e.g. Dietz, Fitzgerald \& Shwom, 2005; Doran, Hanss, \& Larsen, 2016; Hindley \& Font, 2014) while others have not addressed the full range of value orientations (e.g. Kim et al., 2006 focus only on biospheric values while Komppula, Honkanen, Rossi and Kolesnikova, 2018 only consider the two broadest categories of self-enhancement and self-transcendence values). Likewise, several studies that claim to consider values actually examine worldviews (measured by NEP: e.g. Kim et al., 2006; Zografos \& Allcroft, 2007) or traits (measured by VALS: e.g. Valentine \& Powers, 2013) instead of values as guiding principles in life (see Dietz et al., 2005 and Perkins \& Brown, 2012 for the distinction). Furthermore, values have usually been studied in the context of a specific type of tourism such as ecotourism (Perkins \& Brown, 2012), backpack and volunteer tourism (Ooi \& Laing, 2010), indigenous tourism (Vermeersch et al., 2016), or agritourism (Nickerson, Black, \& McCool, 2001). While these studies have advanced the understanding of the relationship between value orientations and specific sustainable tourism offers, it is still unknown whether tourists in general - and not only those already engaged in sustainable tourism - cherish self-transcendence values and might, therefore, be potentially interested in a sustainable tourism proposition. Investigating tourists' value orientations without reference to a specific type of tourism is important because the literature suggests that egocentrism drives all (Wheeller, 2005) or increasingly more tourists (Valentine \& Powers, 2013). If this would be the case, then the future of sustainable tourism is rather dim because, as mentioned above, an egoistic value orientation generally does not lead to sustainable choices (Canavan, 2017; Perkins \& Brown, 2012; Steg et al., 2014). Summing up, there are still unanswered questions about young tourists' values, and in particular whether alongside self-enhancement (hedonic and egoistic) value orientations, they also cherish self-transcendence (altruistic and biospheric) value orientations.

\section{Travel Motivations}

Values influence actions only indirectly. To overcome the often-observed gap between an individual's exposed values and his/her actions, values should be studied together with more proximate causes such as motivations (Kollmuss \& Agyeman, 2002). Motivation is a crucial element of human action and has become the subject of study of different disciplines such as psychology, sociopsychology, and marketing (Fodness, 1994; Gillison et al., 2019). Consequently, a large amount of travel motivations has been individuated. For example, in their seminal study on travel motivations, Pearce and Lee (2005) listed quest for novelty, intellectual cultivation and learning, fun and relaxation, enjoying peace and tranquillity, experiencing the beauty of nature, socializing, and romance. While this and other studies (e.g., Higgins-Desbiolles, 2006; Ivanov, 2010; Perkins \& Grace, 2009; Proyrungroj, 2020; Richards, 2015; Smith, Deery \& Puzko, 2010; Stone \& Patrick, 2013; Wheeller, 2005; Yousaf, Amin, \& Santos, 2018) have contributed to the understanding of motivation as a multidimensional phenomenon, they have been criticized for yielding only lists of reasons for travelling with limited empirical support and marginal attempts at categorization (Fodness, 1994). The most widely accepted categorisation of travel motivations is the distinction between socio-psychological (push) factors internal to the individual and (pull) factors related to the attractiveness of the tourist destination (Crompton, 1979). The boundary between external and internal motivations has, however, proven elusive, limiting the distinction's 
explanatory power (Goossens, 200o). An alternative categorization of motivations as leisure functions (Fodness, 1994) has found less favour in tourism research but has been largely supported in a recent empirical study (Cavagnaro \& Staffieri, 2015). Fodness' (1994) and Cavagnaro and Staffieri's (2015) categorization distinguishes between the motivations based on self-enhancement values (such as the motivation Fun in Fodness, 1994, and Escapism and Relaxation in Cavagnaro \& Staffieri, 2015) from the motivations based on self-transcendence values (such as the motivation Social Interaction in Fodness, 1994, and Culture in Cavagnaro and Staffieri, 2015). Thanks to its connection to value orientations, the categorization of motivations as leisure functions is particularly interesting for the present research aiming at segmenting young tourists on the basis of their value orientations and travel motivations.

Regarding young travellers' motivations, a similar lack of consensus is visible as in the literature on youngsters' value orientation (Stone \& Petrick, 2013). Maybe no specific motivations can be attributed to young travellers because ultimately, they share the same motivations that trigger older tourists (Stone \& Petrick, 2013). Alternatively, the lack of clarity about motivations (and values) may be a transient phase in the development from adolescence to adulthood of so-called emerging adults, the age group to which young travellers belong (Arnett, 2006; Cavagnaro et al., 2018; Palmonari, 2011). Exactly due to their delicate status of change, emerging adults need more attention from researchers (Pascuzzo, Cyr \& Moss, 2013). Therefore, it seems warranted to dedicate a new empirical study to youth travellers taking into account the whole range of value orientations and motivations identified by the literature

\section{Socioeconomic Background}

Previous studies have acknowledged that in examining the demand side of tourism, influences from socio-cultural, economic, and political systems should not be overlooked (Beugelsdijk \& Welzel, 2018; Kollmuss \& Agyeman, 2002; Stern et al., 1995). The two countries where data was gathered for this study, China and Italy, differ in their political, economic, and socio-cultural system. While in the last two decades China has been characterized by rapid economic growth and drastic institutional reforms (Gao, Zhang, \& Huang, 2018), Italy has lived through a period of economic and institutional stagnation that has particularly affected young people (Istat, 2015), leading for example to a high youth unemployment rate (Demos \& Pi, 2008). Regarding culture, China is considered as an archetypical Asian collectivist society (Beugelsdijk \& Welzel, 2018) and Italy as a typical representative of Western individualist societies (Manrai \& Manrai, 2011). This cultural divide still exists although some changes have occurred. More specifically, globalisation and improved economic conditions have influenced Chinese values, resulting in increasing individualism and narcissism particularly among youngsters (Cai, Kwan \& Sedikides, 2012; Li \& Ernst, 2015). This shift is also visible in tourists' motivations, where the self is more largely present than might be expected from a Confucian perspective on life (Fu, Cai \& Lehto, 2015; Hourdequin \& Wong, 2005). Although Chinese young tourists have been described as individualistic, narcissistic, and spoiled (MacCannel, 2002), it should be acknowledged that, in China, traditional and modern values still coexist (Gao et al., 2018; Hsu \& Huang, 2016). In Italy, young people's values are also fluctuating, though in a different direction than in China. In a worldwide study, Italian youngsters have been found to be more oriented towards the welfare of others than their peers in other countries (Istituto Giuseppe Toniolo, 2018). This result is confirmed by the World Giving Index (CAF, 2018), where Italy holds place 84 while China is ranked 138. From a neuroscientific perspective, the turn of the Italian youth towards pro-social values can be explained as a mechanism to cope with the stress caused by the recent economic recession (Tomova et al., 2017; Von Dawans et al., 2012). Notwithstanding cultural and socio-economic differences, youth tourism is an important market in both countries. China's 400 million millennials, born from the early 1980 s to the early 2000 , are expected to drive tourism spending and seek more exotic experiences and far-flung destinations than their parents (UNWTO, 2015; Zhao, 
2017). Although Italian youngsters are struggling economically, they embrace travelling as an essential way to express themselves autonomously (National Tourism Observatory, 2011). It is therefore expected that they will keep travelling but choose for easily accessible destinations at affordable prices. Compared to their parents, young people both in China and Italy have developed greater self-determination. This is particularly interesting in the case of China, where under the Approved Destination Status (ADS) scheme, travelling was heavy restricted to all-inclusive package tours (Sparks \& Pan, 2009). Although the ADS policy is still in place, driven by the recent open-to-abroad Chinese policy, Chinese youngsters are increasingly showing more autonomy during their travel (Sparks \& Pan, 2009). Therefore, while justifiably previous studies have tended to approach the Chinese tourists as a single homogenous group, following a suggestion by Jørgensen, Law and King (2017), this study aims at offering a more sophisticated image of both the Chinese and Italian young travellers by first describing their value orientations and motivations to travel, and then segmenting them using both variables. In doing so, it focuses on young people who are travelling independently, i.e., without an accompanying tutor or parent (UNWTO and WYSE Travel Confederation, 2008). Though travelling independently does not mean by definition travelling alone, it requires that the traveller takes responsibility for the decisionmaking process. Arguably, the chosen travel option reflects the young traveller's values and motivations and not the values and motivations of the accompanying tutor (Staffieri, 2016). It should be also noticed that in 2016, China and Italy have signed a tourism exchange agreement and in 2018 a Memorandum of Understanding, which identifies a series of cooperation possibilities aimed at developing sustainable tourism (MiBaCT, sd). In the light of these theoretical and practical considerations, the choice of Italy and China as target countries is justifiable because it serves the research's aim to identify groups of young tourists from different socioeconomic backgrounds.

\section{Study's aim}

The purpose of this study is to identify groups of Chinese and Italian young tourists who can positively respond to a sustainable tourism offer by segmenting them on the basis of their value orientations and travel motivations without reference to a specific tourism experience. This choice is justified because although value orientations are strong predictors of behaviour, it is only when individuals feel the need (i.e., are motivated) to translate their values into action that behaviour occurs (Fodnes, 1994; Gillison et al., 2019). The study's objectives are proposed as follows:

(1) To segment young tourists by considering value orientations and travel motivations simultaneously;

(2) To compare young tourist segments in two countries with different socioeconomic background;

(3) To evaluate which segments (if any) might respond positively to a sustainable tourism offer.

Since this is the first time that value orientations and travel motivations are connected in segmenting young tourists, detailed hypotheses about group differences could not be advanced. In general, however, this study postulated that it was possible to individuate segments of young tourists for whom self-transcendence values are more salient than self-enhancement values and who are driven by nonegocentric motives. Following Canavan (2017) and literature on sustainable behaviour (e.g. Steg et al., 2014), these segments are arguably open to a sustainable tourism offer.

\section{Research Method}

Using a non-probability sampling technique, in 2016 an online questionnaire was conducted among university students in Mainland China and Italy after having received permission from the two universities concerned. Two reminders were provided in order to increase the response rate. The Chinese sample consisted of undergraduate tourism students and the Italian sample of undergraduate and graduate students. Students fall into the same age category as young tourists (16-29, UNWTO and WYSE Travel Confederation, 2008) and have a higher propensity for travelling independently, i.e. 
without an accompanying tutor or parent. Arguably youngsters travelling independently are guided by their own and not their guardians' motivations. Participants meeting this condition were 253 in China and 510 in Italy. The majority of participants is female (70.8\% in China; $73.5 \%$ in Italy) and qualify as young tourists (16-29), with $94.5 \%$ for China; and $53.5 \%$ for Italy falling in the $18-22$ range.

Both samples have been validated against the age and gender of the total student population (Table 1 summarizes the sample's characteristics). In evaluating their family income against the family needs, a majority considered it adequate (69.6\% in China and $58.2 \%$ in Italy). Interestingly, more Chinese than Italian participants scored family resources as excellent ( $16.2 \%$ vs. slightly under $4.1 \%)$. Conversely, fewer Chinese than Italian participants scored resources as scarce (13.0\% vs. 21.2\%). Additionally, $87.4 \%$ of the Chinese and $64.3 \%$ of the Italian participants indicated their proficiency in one or more languages other than their mother tongue. These findings support the profile of the new wave of Chinese travellers as well-educated and relatively well-off (Li \& Ernst, 2015; Simson, 2016) and reflect the weak economic situation of many Italian families after the 2008 economic crisis (Demos \& $\mathrm{Pi}, 2008$ ).

Table 1. Sample's characteristics - China and Italy

\begin{tabular}{|c|c|c|c|c|c|}
\hline & \multirow{2}{*}{\multicolumn{2}{|c|}{ China }} & \multirow{2}{*}{\multicolumn{2}{|c|}{ Italy }} \\
\hline & & & & & \\
\hline Variable & Value & $\begin{array}{l}\text { Number of } \\
\text { respondents }\end{array}$ & Percent & $\begin{array}{l}\text { Number of } \\
\text { respondents }\end{array}$ & Percent \\
\hline \multirow[t]{3}{*}{ Gender } & female & 179 & 70.8 & 375 & $73 \cdot 5$ \\
\hline & male & 74 & 29.2 & 55 & 10.8 \\
\hline & not indicated & - & - & 80 & $15 \cdot 7$ \\
\hline \multirow[t]{3}{*}{ Age } & $18-22$ & 239 & $94 \cdot 5$ & 273 & $53 \cdot 5$ \\
\hline & $23-29$ & 14 & $5 \cdot 5$ & 159 & 31.2 \\
\hline & not indicated & - & - & 78 & $15 \cdot 3$ \\
\hline \multirow{5}{*}{$\begin{array}{l}\text { Family income } \\
\text { against the } \\
\text { family needs }\end{array}$} & completely insufficient & 3 & 1.2 & 3 & 0.6 \\
\hline & scarce & 33 & 13.0 & 108 & 21.2 \\
\hline & sufficient & 176 & 69.6 & 297 & 58.2 \\
\hline & plenty & 41 & 16.2 & 21 & 4.1 \\
\hline & not indicated & - & - & 81 & $15 \cdot 9$ \\
\hline \multirow{5}{*}{$\begin{array}{l}\text { Languages } \\
\text { proficiency } \\
\text { other than } \\
\text { mother tongue }\end{array}$} & $\mathrm{O}$ & 32 & 12.6 & 101 & 19.8 \\
\hline & $1-2$ & 217 & 85.8 & 292 & 57.2 \\
\hline & $3-4$ & 3 & 1.2 & 35 & 6.9 \\
\hline & $5^{-6}$ & 1 & 0.4 & 1 & 0.2 \\
\hline & not indicated & - & - & 81 & 15.9 \\
\hline Total & & 253 & 100.0 & 510 & 100.0 \\
\hline
\end{tabular}

Alongside demographics, the questionnaires measured values and travel motivations. Values have been measured using Schwartz's (1994) nine-point Likert-like scale ranging from 'opposed to my principles' to 'extremely important in my life'. Following Schwartz's (1994) procedure, values have been centred before calculating value orientations. The scale internal consistency is adequate to strong (Table 2). 
Table 2. Value orientations' items

\begin{tabular}{llll}
\hline \multirow{2}{*}{ Value Orientation } & Values & \multicolumn{2}{c}{ Cronbach's alpha } \\
\cline { 2 - 4 } Egoistic & China & Italy \\
\hline Hedonic & $\begin{array}{l}\text { Social power, wealth, authority, influential and } \\
\text { ambitious }\end{array}$ & 0.740 & 0.751 \\
Altruistic & $\begin{array}{l}\text { Pleasure, enjoying life, gratification for oneself } \\
\text { Biospheric }\end{array}$ & $\begin{array}{l}0.649 \\
\text { Equality, a world at peace, social justice, helpful }\end{array}$ & 0.761 \\
\hline & $\begin{array}{l}\text { Respecting the earth, unity with nature, protecting the } \\
\text { environment, preventing pollution }\end{array}$ & 0.870 & 0.698 \\
\hline
\end{tabular}

Motivations have been measured using the scale developed by Staffieri (2016). Participants indicated their level of agreement with 14 statements on a five-point Likert-like scale (Tables 4a and b). Authors double-checked the Chinese and Italian versions of the questionnaire, and back translation was performed as recommended by Sin-wai and Pollard (2001). No issues were found. Multivariate analysis were conducted with the software SPSS. A non-hierarchical cluster analysis, k-means method (Everitt, Landau \& Leese, 2001), has been chosen because it is widely used in consumers' segmentation (Zani \& Cerioli, 2007). Cluster analysis was tested starting from a partition in two clusters and then gradually increasing the number of clusters up to ten. All descriptive and multivariate analyses have been performed by two of the authors independently; the same results were found. APA ethical standards were followed during the research.

\section{Results}

In this section, results are presented starting from value orientations, proceeding to motivations, and concluding with clusters analysis outcomes. The results concerning value orientations and travel motivations are also briefly commented upon, leaving for the discussion section to comment on the results of the clusters' analysis. Participants' value orientations are shown in table 3.

Table 3. Value orientations: averages and independent sample t-test

\begin{tabular}{lllcl}
\hline $\begin{array}{l}\text { Value } \\
\text { Orientations }\end{array}$ & \multicolumn{2}{c}{ Average } & t & Sig. \\
\cline { 2 - 3 } & China & Italy & & \\
\hline Egoistic & -0.859 & -1.747 & 13.520 & 0.000 \\
Hedonic & 0.532 & 0.405 & 1.796 & 0.073 \\
Altruistic & 0.301 & 1.154 & -14.180 & 0.000 \\
Biospheric & 0.373 & 0.727 & -5.464 & 0.000 \\
\hline
\end{tabular}

Table 3 indicates that although several studies have concluded that narcissism and egoism are on the rise among youngsters (e.g., Cai et al., 2012; Twenge \& Foster, 2010), self-transcendence values have not disappeared. It also indicates that there are significant differences between Chinese and Italian participants, except for the hedonic value orientation. These differences confirm literature suggesting 
that the rapid social, cultural, and economic transformation in China has increased individualism and hedonic narcissism (Cai et al., 2012), while the economic decline in Italy has strengthened youngsters' pro-social orientation (Istituto Giuseppe Toniolo, 2018; Tomova et al., 2017; Von Dawans et al., 2012).

The following two tables show the results of the PCA on travel motivations.

Table 4a. Motivations (China)

\begin{tabular}{|c|c|c|c|c|}
\hline Components & Items & $\begin{array}{l}\text { Component } \\
\text { loadings }\end{array}$ & Eigenvalues & $\begin{array}{l}\text { Variance } \\
\text { explained }\end{array}$ \\
\hline \multirow{5}{*}{$\begin{array}{l}\text { Fun } \mathcal{E} \\
\text { Freedom }\end{array}$} & To relax & 0.830 & \multirow[t]{5}{*}{3.049} & \multirow[t]{5}{*}{21.8} \\
\hline & To have fun & 0.804 & & \\
\hline & To have a break from everyday life & 0.663 & & \\
\hline & To interact with my friends & 0.630 & & \\
\hline & To feel more independent & 0.559 & & \\
\hline \multirow{5}{*}{$\begin{array}{l}\text { Nature \& } \\
\text { Culture }\end{array}$} & To be in contact with nature & 0.799 & \multirow[t]{5}{*}{2.765} & \multirow[t]{5}{*}{19.8} \\
\hline & To experience beautiful natural landscapes & 0.796 & & \\
\hline & To see the beauty of the place & 0.658 & & \\
\hline & $\begin{array}{l}\text { To observe animals that are not living in the } \\
\text { country I came from }\end{array}$ & 0.620 & & \\
\hline & To know different cultures & 0.563 & & \\
\hline \multirow[t]{4}{*}{$\begin{array}{l}\text { Socialization } \\
\text { and vogue }\end{array}$} & $\begin{array}{l}\text { Because by discussing with my friends on social } \\
\text { media (such as Facebook) I raised the } \\
\text { impression that I would do it }\end{array}$ & 0.800 & \multirow[t]{4}{*}{2.304} & \multirow[t]{4}{*}{16.5} \\
\hline & To study/or work & 0.699 & & \\
\hline & $\begin{array}{l}\text { Because most people think that it is necessary } \\
\text { to do at least once in the life }\end{array}$ & 0.671 & & \\
\hline & To interact with other people & 0.639 & & \\
\hline
\end{tabular}

Total Variance Explained $=58.1$

$\mathrm{KMO}=0.836$

Table 4b. Motivations (Italy)

\begin{tabular}{|c|c|c|c|c|}
\hline Components & Items & $\begin{array}{l}\text { Component } \\
\text { loadings }\end{array}$ & Eigenvalues & $\begin{array}{l}\text { Variance } \\
\text { explained }\end{array}$ \\
\hline \multirow{3}{*}{ Nature } & To be in contact with nature & 0.866 & \multirow{3}{*}{2.550} & \multirow[t]{3}{*}{18.2} \\
\hline & To experience beautiful natural landscapes & 0.821 & & \\
\hline & $\begin{array}{l}\text { To observe animals that are not living in the } \\
\text { country I came from }\end{array}$ & 0.743 & & \\
\hline \multirow{5}{*}{$\begin{array}{l}\text { Escapism and } \\
\text { Relaxation }\end{array}$} & To have fun & 0.820 & \multirow[t]{5}{*}{2.548} & \multirow[t]{5}{*}{18.2} \\
\hline & To have a break from everyday life & 0.730 & & \\
\hline & To relax & 0.714 & & \\
\hline & To see the beauty of the place & 0.535 & & \\
\hline & To interact with my friends & 0.486 & & \\
\hline \multirow{4}{*}{$\begin{array}{l}\text { Culture and } \\
\text { independence }\end{array}$} & To interact with other people & 0.833 & \multirow[t]{4}{*}{2.178} & \multirow[t]{4}{*}{15.6} \\
\hline & To feel more independent & 0.767 & & \\
\hline & To know different cultures & 0.586 & & \\
\hline & To study and work & 0.579 & & \\
\hline \multirow[t]{2}{*}{ Vogue } & $\begin{array}{l}\text { Because I raised to my friends on the social } \\
\text { media (e.g. Facebook) the expectation that I } \\
\text { would take this trip }\end{array}$ & 0.842 & \multirow[t]{2}{*}{1.581} & \multirow[t]{2}{*}{11.3} \\
\hline & $\begin{array}{l}\text { Because most people think that it is necessary } \\
\text { to do at least once in the life }\end{array}$ & 0.752 & & \\
\hline
\end{tabular}

Total Variance Explained $=63.3 \quad \mathrm{KMO}=0.733$ 
The tables above show that travel motivations can be reduced to fewer components highlighting relations between the measured items (Tacq, 2007). The PCA suggested three components for the Chinese sample and four for the Italian sample. The differences found are understandable from a socioeconomic perspective. The first component extracted for China reflects the rise of individualism and hedonism driven by economic growth and globalization (Cai et al., 2012; Fu et al., 2015; MacCannel, 2002). Conversely, the first component extracted for Italy reflects youngsters' anti-individualistic reaction to economic stagnation (Tomova et al., 2017; Von Dawans et al., 2012). Considering the third and (for Italy) fourth component, it can be argued that while for the Italian participants connecting to others is a way to reach independence, for the Chinese participants the relationship with others is still framed from a collectivistic perspective (Hsu \& Huang, 2016). Consequently, while Vogue clusters with Socialization for Chinese young travellers, it is a separate motivation for their Italian peers.

Table 5a and 5b report the clusters analysis' output for China and Italy respectively.

Table 5a. $R^{2}$ Index for value orientations, motivation components and $R^{2}$ global for the number of partitions solutions (China)

\begin{tabular}{|c|c|c|c|c|c|c|c|c|c|}
\hline \multirow{2}{*}{ Components } & \multicolumn{9}{|c|}{ Number of clusters } \\
\hline & 2 & 3 & 4 & 5 & 6 & 7 & 8 & 9 & 10 \\
\hline Hedonic & 0.127 & 0.254 & 0.383 & 0.432 & 0.477 & 0.425 & 0.412 & 0.466 & 0.615 \\
\hline Egoistic & 0.327 & 0.409 & 0.382 & 0.428 & 0.408 & 0.331 & $0.45^{2}$ & 0.475 & 0.543 \\
\hline Altruistic & 0.164 & 0.139 & 0.130 & 0.207 & 0.206 & 0.241 & 0.267 & 0.347 & 0.370 \\
\hline Biospheric & 0.377 & 0.420 & 0.386 & 0.420 & 0.479 & 0.435 & 0.492 & 0.464 & 0.469 \\
\hline $\begin{array}{l}\text { MOTIVATION: Fun } \mathcal{E} \\
\text { Freedom }\end{array}$ & 0.157 & 0.165 & 0.350 & 0.266 & 0.424 & 0.567 & 0.565 & 0.622 & 0.567 \\
\hline $\begin{array}{l}\text { MOTIVATION: Nature } \mathcal{E} \\
\text { Culture }\end{array}$ & 0.328 & 0.242 & 0.341 & 0.298 & 0.411 & 0.444 & 0.439 & 0.533 & 0.492 \\
\hline $\begin{array}{l}\text { MOTIVATION: Socialization } \\
\text { and vogue }\end{array}$ & 0.003 & 0.309 & 0.375 & 0.520 & 0.347 & 0.586 & 0.562 & 0.567 & 0.633 \\
\hline Global R-squared & 0.212 & 0.277 & 0.335 & 0.376 & 0.393 & 0.433 & 0.455 & 0.496 & 0.527 \\
\hline Global R-squared increase & & 0.065 & 0.058 & 0.032 & 0.026 & 0.040 & 0.023 & 0.041 & 0.031 \\
\hline
\end{tabular}


Table 5b. $R^{2}$ Index for value orientations, motivation components and $R^{2}$ global for the number of partitions solutions (Italy)

\begin{tabular}{|c|c|c|c|c|c|c|c|c|c|}
\hline \multirow{2}{*}{ Components } & \multicolumn{9}{|c|}{ Number of clusters } \\
\hline & 2 & 3 & 4 & 5 & 6 & 7 & 8 & 9 & 10 \\
\hline Hedonic & 0.030 & 0.042 & 0.047 & 0.085 & 0.199 & 0.106 & 0.490 & 0.495 & 0.211 \\
\hline Egoistic & 0.520 & 0.469 & 0.500 & 0.471 & 0.481 & 0.564 & 0.490 & 0.495 & 0.594 \\
\hline Altruistic & 0.340 & 0.235 & 0.279 & 0.308 & 0.287 & 0.331 & 0.490 & 0.495 & 0.396 \\
\hline Biospheric & 0.353 & 0.379 & 0.362 & 0.312 & 0.323 & 0.381 & 0.490 & 0.495 & 0.371 \\
\hline MOTIVATION: Nature & 0.083 & 0.171 & 0.267 & 0.383 & 0.380 & 0.468 & 0.490 & 0.495 & 0.440 \\
\hline $\begin{array}{l}\text { MOTIVATION: Escapism } \\
\text { and Relaxation }\end{array}$ & 0.003 & 0.023 & 0.083 & 0.375 & 0.504 & 0.512 & 0.490 & 0.495 & $0.55^{0}$ \\
\hline $\begin{array}{l}\text { MOTIVATION: Culture and } \\
\text { independence }\end{array}$ & 0.001 & 0.008 & 0.163 & 0.120 & 0.321 & 0.304 & 0.490 & 0.495 & 0.463 \\
\hline MOTIVATION: Vogue & 0.104 & 0.555 & 0.586 & 0.524 & 0.501 & 0.514 & 0.490 & 0.495 & 0.625 \\
\hline Global R-squared & 0.179 & 0.235 & 0.286 & 0.322 & 0.375 & 0.398 & 0.428 & 0.449 & 0.456 \\
\hline Global R-squared increase & & 0.056 & 0.051 & 0.036 & 0.052 & 0.023 & 0.031 & 0.020 & 0.008 \\
\hline
\end{tabular}

Tables $6 a$ and $6 \mathrm{~b}$ show the ANOVA outcomes. The variables with a greater capability to discriminate between the Chinese and Italian sample are in bold. As stated above, segments of young travellers were clustered by simultaneously considering their value orientations and travel motivations. The best fit was reached with 4 clusters for the Chinese, and 6 for the Italian sample.

Table 6a. ANOVA and $R^{2}$ index for the number of clusters (China)

\begin{tabular}{|c|c|c|c|c|c|c|c|}
\hline \multirow[b]{2}{*}{ Variables } & \multicolumn{2}{|l|}{ Cluster } & \multicolumn{2}{|l|}{ Error } & \multirow[b]{2}{*}{$\mathbf{F}$} & \multirow[b]{2}{*}{ Sig. } & \multirow[b]{2}{*}{$\mathbf{R}^{2}$} \\
\hline & $\begin{array}{l}\text { Mean } \\
\text { Square }\end{array}$ & df & $\begin{array}{l}\text { Mean } \\
\text { Square }\end{array}$ & df & & & \\
\hline Hedonic & 30.175 & 3 & 0.587 & 249 & 51.428 & 0.000 & 0.383 \\
\hline Egoistic & 21.574 & 3 & 0.420 & 249 & 51.307 & 0.000 & 0.382 \\
\hline Altruistic & 6.586 & 3 & 0.529 & 249 & 12.448 & 0.000 & 0.130 \\
\hline Biospheric & 24.174 & 3 & 0.464 & 249 & 52.074 & 0.000 & 0.386 \\
\hline MOTIVATION: Fun E freedom & $29 \cdot 360$ & 3 & 0.658 & 249 & 44.600 & 0.000 & $0.35^{0}$ \\
\hline MOTIVATION: Nature E culture & 28.686 & 3 & 0.666 & 249 & 43.044 & 0.000 & 0.341 \\
\hline $\begin{array}{l}\text { MOTIVATION: Socialization and } \\
\text { vogue }\end{array}$ & 31.487 & 3 & 0.633 & 249 & $49 \cdot 767$ & 0.000 & 0.375 \\
\hline
\end{tabular}


Table 6b. ANOVA and $R^{2}$ index for the number of clusters (Italy)

\begin{tabular}{|c|c|c|c|c|c|c|c|}
\hline \multirow[b]{2}{*}{ Variables } & \multicolumn{2}{|c|}{ Cluster } & \multicolumn{2}{|l|}{ Error } & \multirow[b]{2}{*}{$F$} & \multirow[b]{2}{*}{ Sig. } & \multirow[b]{2}{*}{$\mathbf{R}^{2}$} \\
\hline & $\begin{array}{l}\text { Mean } \\
\text { Square }\end{array}$ & df & $\begin{array}{l}\text { Mean } \\
\text { Square }\end{array}$ & df & & & \\
\hline Hedonic & 13.696 & 5 & 0.546 & 504 & 25.097 & 0.000 & 0.199 \\
\hline Egoistic & 41.503 & 5 & 0.444 & 504 & 93.473 & 0.000 & 0.481 \\
\hline Altruistic & 18.452 & 5 & 0.455 & 504 & 40.519 & 0.000 & 0.287 \\
\hline Biospheric & 20.720 & 5 & 0.431 & 504 & 48.058 & 0.000 & 0.323 \\
\hline MOTIVATION: Nature & 38.688 & 5 & 0.626 & 504 & 61.790 & 0.000 & 0.380 \\
\hline $\begin{array}{l}\text { MOTIVATION: } \\
\text { Escapism and relaxation }\end{array}$ & 51.270 & 5 & 0.501 & 504 & 102.277 & 0.000 & 0.504 \\
\hline $\begin{array}{l}\text { MOTIVATION: } \\
\text { Culture and independence }\end{array}$ & 32.701 & 5 & 0.686 & 504 & $47 \cdot 703$ & 0.000 & 0.321 \\
\hline MOTIVATION: Vogue & 51.016 & 5 & 0.504 & 504 & 101.259 & 0.000 & 0.501 \\
\hline
\end{tabular}

The final cluster centres permit the clusters' description, as shown in Table $7 \mathrm{a}$ for China and $7 \mathrm{~b}$ for Italy.

Table 7a. Number of cases and Final Cluster Centres (China)

Final Cluster Centres

\begin{tabular}{lllll}
\cline { 2 - 4 } Variables & \multicolumn{3}{c}{ Cluster } \\
\cline { 2 - 5 } & $\mathbf{1}$ & $\mathbf{2}$ & $\mathbf{3}$ & $\mathbf{4}$ \\
\hline Hedonic & -0.219 & 1.077 & -0.091 & 0.995 \\
Egoistic & -1.184 & -1.424 & -0.298 & -0.307 \\
Altruistic & 0.716 & 0.239 & 0.300 & -0.014 \\
Biospheric & 0.929 & 0.732 & 0.141 & -0.348 \\
MOTIVATION: Fun E Freedom & 0.423 & 0.258 & -1.403 & 0.038 \\
MOTIVATION: Nature E Culture & 0.600 & 0.364 & -0.124 & -0.816 \\
MOTIVATION: Socialization and Vogue & 0.693 & -0.881 & 0.416 & -0.003 \\
Number of cases & 69 & $\mathbf{7 1}$ & 36 & 77 \\
\hline
\end{tabular}


Table 7b. Number of cases and Final Cluster Centres (Italy)

Final Cluster Centres

\begin{tabular}{lcccccc}
\cline { 2 - 6 } Variables & \multicolumn{7}{c}{ Cluster } \\
\cline { 2 - 7 } & $\mathbf{1}$ & $\mathbf{2}$ & $\mathbf{3}$ & $\mathbf{4}$ & $\mathbf{5}$ & $\mathbf{6}$ \\
\hline Hedonic & 0.129 & 0.702 & 0.623 & 0.299 & -0.317 & 0.632 \\
Egoistic & -1.215 & -2.604 & -1.526 & -1.776 & -2.169 & -0.904 \\
Altruistic & 0.817 & 1.558 & 1.085 & 1.209 & 1.660 & 0.531 \\
Biospheric & 0.605 & 1.171 & 0.356 & 0.786 & 1.288 & 0.125 \\
MOTIVATION: Nature & 0.564 & 0.093 & -1.048 & -0.655 & 0.873 & 0.013 \\
$\begin{array}{l}\text { MOTIVATION: } \\
\text { Escapism and relaxation }\end{array}$ & 0.113 & 0.453 & 0.486 & -2.046 & -0.207 & 0.122 \\
$\begin{array}{l}\text { MOTIVATION: } \\
\text { Culture and independence }\end{array}$ & 0.106 & 0.450 & -0.873 & 0.484 & -0.739 & 0.406 \\
MOTIVATION: Vogue & $\mathbf{1 . 9 2 5}$ & -0.344 & 0.001 & -0.150 & -0.352 & -0.304 \\
Number of cases & $\mathbf{5 9}$ & $\mathbf{1 2 6}$ & $\mathbf{8 2}$ & $\mathbf{4 9}$ & $\mathbf{8 2}$ & $\mathbf{1 1 2}$ \\
\hline
\end{tabular}

\section{Discussion and Implications}

As amply demonstrated by existing research, an altruistic and biospheric value orientation positively influences sustainable choices (e.g. Steg et al., 2014). This study postulated the possibility to individuate segments of young tourists for whom a self-transcendence value orientation is more salient than a selfenhancement one and who are driven by non-egocentric travel motives. Arguably, these segments seek tourism offers such as sustainable tourism that emphasise involvement and depth above mere enjoyment (Canavan, 2017). Notwithstanding some differences, results suggest that the postulated segments can be found in both the Chinese and Italian sample. The discussion will start from the most promising segments, proceed to clusters that may choose sustainable tourism offers only under certain conditions, and conclude with clusters that may never consider such offers.

Most promising clusters for a sustainable tourism offer

With slightly more than one-quarter of the sample (27.3\%), the first Chinese cluster is characterized by the highest altruistic and biospheric value orientations among the four clusters, and an aversion towards egoistic values. Moreover, socialization, nature, and culture are pointed at as the travel motive. Combining high self-transcendence values and non-egocentric motivations, this cluster represents the most natural target for a sustainable tourism proposition. From an international perspective, it is reminiscent of the so-called true (Perkins \& Brown, 2012) or motivated (Lindberg, 1991) eco-tourists who care about the natural and social environment. Considering research on Chinese collectivist values (Hourdequin \& Wong, 2005), this cluster can be labelled as 'Junzi' (gentlemen). Junzi people are able to control the basic greediness of human nature and, consequently, produce harmony between humans and nature (Hourdequin \& Wong, 2005). Interestingly, socializing and following the current trends also motivate this cluster. This is in line with the collectivistic values underlying Junzi, as Junzi is an expression of the Confucian belief about relationships constructing the self (Li \& Ernst, 2015). Therefore, 
though Junzi people can master circumstances, they are also influenced by their social network (Huang \& Hsu, 2005; Li \& Ernst, 2015). Consequently, respondents falling in the 'gentlemen' cluster may engage with sustainability not only because they desire to foster the harmony between humans and nature, but also because they wish to increase their status among peers (Griskevicius, Tybur \& Van den Bergh, 2010; Wheeller, 2005).

Similar to the Junzi cluster, the fifth Italian cluster (16.1\% of the sample) represents a natural opportunity for sustainable tourism because it holds altruistic and biospheric values higher than average and is motivated by Nature. Bonnes, Carrus and Passafaro (2006) found that individuals sensitive to environmental issues prefer forms of tourism that bring them in contact with nature. While people may choose pro-environmentally for self-serving and anthropocentric motives (Perkins \& Brown, 2012), they are less well and less firmly disposed towards the environment than people motivated by selftranscendence and eco-centric values (Fermani, Crespi \& Stara, 2016), because this group attributes to the environment an intrinsic value not subordinated to its utility for humans (Steg et al., 2014). Arguably, similar to the Junzi, this cluster also includes the so-called true (Perkins \& Brown, 2012) or motivated (Lindberg, 1991) eco tourists. Therefore, this group is labelled 'True eco-tourists'.

The second Chinese cluster, almost as large as the first ( $28.1 \%$ of the sample), is characterized by the highest hedonic value orientation among the four Chinese clusters, a strong biospheric value orientation and an aversion towards egoism. It also represents the largest group (52.1\%) of late adolescent members (21-29 years old), indicating that senior college students/graduates have a higher level of awareness in environmental protection and social responsibility than their junior counterparts (Li, 2017). Though the connection between hedonic and biospheric value orientations is uncommon, it may point to a target group finding joy in protecting nature. Interestingly, this cluster displays a strong aversion to socialization as a travel motivation. It can therefore be concluded that this group is more concerned with enjoying nature and relaxing in solitude (Cohen, 1982) than with forming new relationships (Canavan, 2017). In line with Fodness' (1994) motivational factor punishment minimization, this cluster may see tourism as a pastime which reinforces and protects the ego, furthering potential narcissistic traits (MacCannell, 2002; Perkins \& Brown 2012). However, considering that traditional and modern values still coexist among Chinese youngsters (Gao et al., 2018; Hsu \& Huang, 2016), this cluster's preference for enjoying nature in isolation can also be interpreted through a Taoist lens. Taoism advocates self-transcendence and integration with nature instead of social achievement and self-referenced development (Yip, 2004). Moreover, the cluster's characteristics remind of the Chinese classical idyllists - a 1500-year-old school of Chinese poetry that shares some similarities with the $19^{\text {th }}$ century British Lakeside School (Zhao, 2011). Although these poets believe in Taoism and privilege a hermits' lifestyle, they do not escape from life, and they strongly respect nature because it symbolizes to them the highest level of beauty, kindness, and truth. All things considered, this cluster is labelled the 'Idyllists' and is also considered as open to a sustainable tourism offer.

\section{Clusters open to a sustainable tourism offers under specific conditions}

The first Italian cluster (11.6\% of the Italian sample) is strongly motivated by vogue, while value orientations are not sharply defined, except for an aversion towards egoism. Ranking social desirability above personal choices, this cluster may accept sacrifices and put aside personal needs to get social recognition (Fermani et al., 2016). Being prone to vogue, their travel choices are influenced by celebrities and social media as well (Lee, Scott \& Kim, 2008) and remind of the non-extreme narcissistic millennials who exploit social networks to have more contacts (Bergman, Fearrington, Davenport \& Bergman, 2011). Finally, Nature is ranked by this group as the second-highest motivation of all Italian clusters. Therefore, like the Chinese 'Gentlemen', this Italian group may engage with sustainability to increase their status 
among peers (Griskevicius et al., 2010; Wheeller, 2005). Unlike the Chinese 'Gentlemen', however, these Italian youths do not rate biospheric values higher than altruistic. Arguably, occasional eco-tourists (Lindberg, 1991) are represented in this cluster. This cluster is labelled 'Eco-tourists by vogue' because its members could positively respond to a sustainable tourism proposition if it is endorsed by a celebrity or otherwise status enhancing (Naderi \& Strutton, 2014).

The second Italian cluster, characterized by the highest percentage of very young members $(42.9 \%$ is 18-20 years old), includes almost a quarter (24.7\%) of the sample. It shows a resolute refusal of the egoistic value orientation, and comparatively high scores on the other three value orientations as if respondents were uncertain about their guiding principles in life. In line with studies on the youngest group (19-29) among the emerging adults (Arnett, 2006; Cavagnaro et al., 2018; Palmonari, 2011), this finding is interpreted as a transitory phase in the respondent's development. Looking at motivations, the inclination to Escapism has been more frequently observed in very young travellers (Palmonari, 2011), while the preference accorded to Independence \& Culture is a new finding for this age-group. The overrepresentation of women in the cluster (79.4\%) may offer an explanation. With specific reference to the Italian context, Decataldo, Ruspini, Gilli and Del Greco (2013) observe that women develop their identity by interacting with other people and with the surrounding space; and that travelling offers them a perfect opportunity to do so. Interestingly, embracing both the Escapism \& Relaxation and the Independence \& Culture motivation, this cluster resembles the 'curious tourist' identified recently as a typically Italian form of tourism characterized by the desire to know and get in touch with others (MiBaCT, s.d.). Contrary to the solitary Chinese tourist of the second cluster (the 'Idyllist'), this group approaches tourism as an opportunity for entering into mutually rewarding relationships (Canavan, 2017), and like the so-called global nomads, it will most probably seek contact with local people at the destination (Richards, 2015). It may consequently be open to pro-social forms of tourism. Therefore, following the study by MiBaCT(s.d.), this Italian cluster is labelled 'curious tourists'.

The fourth cluster (9.6\% of the Italian respondents) rejects Escapism \& Relaxation as motivation and positively embraces only the Culture \& Independence motivation. Remembering Canavan (2017), it may be concluded that it looks at travelling as an opportunity for meaningful cultural and social exchange, and like Italian cluster two, may be interested in pro-social tourism offers. The label proposed is 'Grand Tour Millennials' with reference to the $18^{\text {th }}$ and $19^{\text {th }}$ century travelling for cultural exploration and personal development purposes.

\section{Clusters not (yet) open to a sustainable tourism offer}

The third Chinese cluster is the smallest (14.2\% of the sample) and does not present a marked preference for a value orientation or travel motivation. Two explanations may be offered for this result. One interpretation considers that in this cluster, the very young traveller (18-20) is overrepresented (69.4\%) and explains the lack of a definite value orientation as a transient, developmental phase in the youngsters' identity construction (Arnett, 2006; Cavagnaro et al., 2018; Palmonari, 2011). The other interpretation points to the desire-free lifestyle that has recently emerged in China and whose adepts are known as 'Buddhist-style young' (佛系青年 in Chinese; Tao, 2018). The Buddha-like thinking prevalent in Chinese youth subculture is perceived by mainstream society as a negative, contradictory, and deconstructive tendency, caused by pressure, anxiety, or frustration brought by the rapidly developing socio-economy and the conflict between Eastern and Western values aroused by globalisation and multiculturalism ( $\mathrm{Di}, 2018)$. Buddhist-style youth perceive the value education provided by Chinese schools and universities as ideological and political. They consequently resist any appeal to taking responsibility ( $\mathrm{Li}, 2 \mathrm{O16}$ ), which could explain the weaving value orientation of this cluster. Among travel motivations, only Socialisation and Vogue is marked positively while Fun and Freedom is strongly 
rejected. This may indicate that at least momentarily, traditional collectivistic values in which the self is seen as a product of its relationships slightly prevail in this group above individualistic values (Hourdequin \& Wong, 2005). Therefore, this cluster is labelled the 'Collectivists in transition'.

The last and largest Chinese cluster (30.4\% of the sample), with a higher percentage of males $(41.6 \%)$, presents the second-highest hedonic value orientation. This value orientation is the only one positively loaded, supporting Gong's (2008) findings that male urban residents are significantly less environmentally friendly than women. Fun and Freedom is the only slightly positive travel motivation while Nature and Culture is clearly rejected. This cluster fits Simson's (2016) assessment of the Chinese millennials as spoiled. It also mimics the Western entitlement generation (Debevec, Schewe, Madden \& Diamond, 2013) symbolized by the pouting 'duckface' in selfies where the individual ego and hedonistic pleasure is prioritized over the surroundings (Dinhopl \& Gretzel, 2016). Considering that a pure hedonic value orientation is generally antagonistic to sustainable behaviour, it may be concluded that youngsters in this cluster are not particularly concerned with the consequences of their behaviour on other people or the natural environment. Therefore, the proposed label for this cluster is 'Unconcerned Hedonists'.

The third Italian cluster ( $16.1 \%$ of the respondents) resembles the fourth in terms of values, yet it is exclusively motivated by Escapism \& Relaxation. In line with Canavan (2017), it can be argued that higher hedonic and lower self-transcendence values reinforce the tendency towards merely pleasurable forms of tourism. Entertainment and recreational activities are sought after as a way to elude the real problems of life (Woody, 2018). Psychologically, the choice for escapism may be interpreted as a coping strategy to avoid problems and responsibilities at the cost of getting estranged from reality (Crocetti, Fermani \& Pojaghi, 2009). Therefore, considering their rejection of 'Nature' as a motivation on one side and on the other side the largely negative links between hedonism and ethical forms of tourism (Canavan, 2017), the third cluster qualifies as the least open to pro-social and pro-environmental forms of tourism. Consequently, it is labelled 'Sun and Sand'.

The sixth Italian cluster is the second largest (22.0\% of the sample) and is characterized by the least contrary tendency towards an egocentric and the second-highest score on a hedonic value orientation. There is, moreover, no clear preference for a specific motivation. This cluster may be constituted by the so-called indifferent or unfounded tourists uncovered in the spa (Sánchez Rivero, Rodríguez Rangel \& Andrades Caldito, 2016) and wine (Gatti \& Maroni, 2004) tourism research. Although the study sampled only youngsters who travelled in the year before the survey, this result can be interpreted as a move away from tourism in the light of the fact that $25 \%$ of Italians have reduced travel expenses to cope with the economic crisis (Demos \& Pi, 2008). The label proposed is, therefore, 'Indifferent Tourists'.

Summing up results so far, it is noticeable that, notwithstanding differences in socio-economic background, in both China and Italy, segments can be identified where high self-transcendence values connect to nature-related travel motivations (cluster 1 and 2 in China and cluster 5 in Italy; see Table 8). On the basis of the considerable amount of research consistently showing the impact of value orientations on behaviour (Steg et al., 2014; Stern et al., 1995), it can be argued that these clusters are open to a sustainable tourism offer. Following the same reasoning, clusters could be identified that may be interested in sustainable tourism under special circumstances, such as when the offer is endorsed by a celebrity, enhance the travellers' status or is framed pro-socially (clusters 1,2 and 4 in Italy). In other words, more than half of the Chinese (55.1\%) and Italian (62.3\%) sample may be interested in a sustainable tourism offer. 
Table 8. Summary of main results

\section{Clusters China}

\begin{tabular}{|c|c|c|c|}
\hline Junzi (gentlemen) & 2) Idyllists & $\begin{array}{l}\text { 3) Collectivists in } \\
\text { transition }\end{array}$ & $\begin{array}{l}\text { 4) Unconcerned } \\
\text { Hedonists }\end{array}$ \\
\hline $\begin{array}{l}\text { value orientation: highest } \\
\text { altruistic and biospheric; } \\
\text { aversion towards egoistic } \\
\text { values } \\
\text { travel motivation: } \\
\text { socialization, nature, and } \\
\text { culture } \\
\text { open to sustainable tourism } \\
\text { offer: yes because the cluster } \\
\text { combines high self- } \\
\text { transcendence values and } \\
\text { non-egocentric motivations }\end{array}$ & $\begin{array}{l}\text { value orientation: } \\
\text { highest hedonic value } \\
\text { orientation; strong } \\
\text { biospheric value } \\
\text { orientation and an } \\
\text { aversion towards egoism } \\
\text { travel motivation: strong } \\
\text { aversion to socialization } \\
\text { open to sustainable } \\
\text { tourism offer: yes, if it } \\
\text { emphasises enjoying } \\
\text { nature in isolation }\end{array}$ & $\begin{array}{l}\text { value orientation: no } \\
\text { marked preference } \\
\text { travel motivation: no } \\
\text { marked preference } \\
\text { open to sustainable } \\
\text { tourism offer: not to } \\
\text { be determined due } \\
\text { to no marked value } \\
\text { orientation and } \\
\text { travel motivation }\end{array}$ & $\begin{array}{l}\text { value orientation: second } \\
\text { highest in hedonic value } \\
\text { orientation } \\
\text { travel motivation: } \\
\text { open to sustainable tourism } \\
\text { offer: no, this cluster is not } \\
\text { concerned with the } \\
\text { consequences of behaviour } \\
\text { on other people or the } \\
\text { natural environment }\end{array}$ \\
\hline $69(27 \cdot 3 \%)$ & $71(28.1 \%)$ & $36(14.2 \%)$ & $77(30.4 \%)$ \\
\hline
\end{tabular}

Clusters Italy

\begin{tabular}{|c|c|c|c|c|c|c|c|c|c|}
\hline 1) & $\begin{array}{l}\text { Eco- } \\
\text { tourists by } \\
\text { vogue }\end{array}$ & $\begin{array}{l}\text { Curious } \\
\text { tourists }\end{array}$ & 3) & $\begin{array}{l}\text { Sun and } \\
\text { Sand }\end{array}$ & 4) & $\begin{array}{l}\text { Grand Tour 5) } \\
\text { Millennials }\end{array}$ & $\begin{array}{l}\text { True eco- } \\
\text { tourists }\end{array}$ & 6 & $\begin{array}{l}\text { Indifferent } \\
\text { Tourists }\end{array}$ \\
\hline
\end{tabular}

\begin{tabular}{|c|c|c|c|c|c|}
\hline $\begin{array}{l}\text { value } \\
\text { orientation: } \\
\text { aversion } \\
\text { towards egoism } \\
\text { travel } \\
\text { motivation: } \\
\text { Vogue; Nature } \\
\text { is ranked } \\
\text { second highest } \\
\text { open to } \\
\text { sustainable } \\
\text { tourism offer: } \\
\text { yes if endorsed } \\
\text { by a celebrity } \\
\text { or otherwise } \\
\text { status } \\
\text { enhancing }\end{array}$ & $\begin{array}{l}\text { value } \\
\text { orientation: } \\
\text { resolute refusal } \\
\text { of the egoistic } \\
\text { value } \\
\text { orientation; } \\
\text { high scores on } \\
\text { the others } \\
\text { travel } \\
\text { motivation: } \\
\text { Escapism \& } \\
\text { relaxation and } \\
\text { Independence \& } \\
\text { Culture } \\
\text { open to } \\
\text { sustainable } \\
\text { tourism offer: } \\
\text { very probably to } \\
\text { pro-social forms }\end{array}$ & $\begin{array}{l}\text { value } \\
\text { orientation: } \\
\text { aversion } \\
\text { towards } \\
\text { egoism } \\
\text { travel } \\
\text { motivation: } \\
\text { Escapism \& } \\
\text { Relaxation } \\
\text { exclusively } \\
\text { open to } \\
\text { sustainable } \\
\text { tourism offer: } \\
\text { no, due to } \\
\text { self-centred } \\
\text { motivation }\end{array}$ & $\begin{array}{l}\text { value } \\
\text { orientation: } \\
\text { aversion } \\
\text { towards egoism } \\
\text { travel } \\
\text { motivation: } \\
\text { rejects Escapism } \\
\text { \& Relaxation; } \\
\text { embraces } \\
\text { Culture \& } \\
\text { Independence } \\
\text { open to } \\
\text { sustainable } \\
\text { tourism offer: } \\
\text { very probably to } \\
\text { pro-social forms }\end{array}$ & $\begin{array}{l}\text { value orientation: } \\
\text { altruistic and } \\
\text { biospheric values } \\
\text { higher than } \\
\text { average } \\
\text { travel motivation: } \\
\text { nature } \\
\text { openness to } \\
\text { sustainable } \\
\text { tourism offer: yes, } \\
\text { because the } \\
\text { cluster combines } \\
\text { high self- } \\
\text { transcendence } \\
\text { values and non- } \\
\text { egocentric } \\
\text { motivations }\end{array}$ & $\begin{array}{l}\text { value orientation: } \\
\text { the least contrary } \\
\text { tendency towards } \\
\text { an egocentric and } \\
\text { the second- } \\
\text { highest score on a } \\
\text { hedonic } \\
\text { travel motivation: } \\
\text { Fun and freedom; } \\
\text { no marked } \\
\text { preference } \\
\text { open to } \\
\text { sustainable } \\
\text { tourism offer: no, } \\
\text { due to focus on } \\
\text { self-enhancement } \\
\text { values }\end{array}$ \\
\hline $59(11.6 \%)$ & $126(24 \cdot 7 \%)$ & $82(16.1 \%)$ & $49(9.6 \%)$ & $82(16.1 \%)$ & $112(22 \%)$ \\
\hline
\end{tabular}

The main practical implication of this study is that professionals should approach young travellers as a heterogeneous group and develop dedicated tourism offers to cater for different segments. The main theoretical implication is that recent research in the Netherlands qualifying the statement that youngsters are an entitled, hedonic generation mainly inspired by self-enhancing values (Cavagnaro et al., 2018; Cavagnaro \& Staffieri, 2015), is confirmed. Undeniably, the results also indicate that some 
young travellers cherish higher hedonic and egoistic values (cluster 4 in China and 6 in Italy) while others are undecided on the guiding principles of their lives (Cluster 3 in China and 1 in Italy). While these clusters confirm literature on the importance of hedonic enjoyment for young travellers, taking all clusters into account, this study unveils young travellers as a multi-faceted and non-homogeneous generation of which a consistent component is open to a sustainable tourism offer.

\section{Conclusion}

In the face of literature suggesting that individualism and narcissism characterize the younger generation (Twenge \& Foster, 2010), this study aimed at identifying segments of young tourists open to a sustainability offer by clustering the respondents by their value orientations and travel motivations, without reference to a specific tourism experience. China and Italy were singled out as the study's locations to address the influence of different socio-economic conditions on value orientations (Stern et al., 1995).

This study contributes to the understanding of youngsters' travel motives by reducing the list of travel motivations derived from existing literature to fewer underlying components. Out of these components, some connect non-egocentric motivations, such as travelling to experience nature and culture; while other tied together hedonic and escapism motivations, such as travelling to have fun and have a break from everyday life. It also contributes to the understanding of young travellers' value orientations, as briefly stated above. Most importantly, by clustering Chinese and Italian respondents on the basis of their value orientations and travel motivations, it offers a sophisticated picture of young tourists where target groups open to a sustainable tourism offer are distinguished from target groups open to such an offer only under certain conditions and from segments not (yet) open to it. In other words, this finding suggests that the lack of consensus in the literature on young tourists' openness towards meaningful tourism experiences, such as sustainable tourism, may be explained as a consequence of focussing on one of the individuated target groups only. Finally, that a majority of young travellers may be open for a sustainable tourism offer is a remarkable result because it has been found in two countries that greatly differ in their socio-economic background and among travellers that were not selected on the basis of their engagement with sustainable tourism. This finding also offers an interesting opportunity for the recovery of European tourism after the COVID-19 pandemic. It may help overcoming the reluctance of some actors in the tourism industry to focus on sustainable travel propositions and, consequently, help steering European tourism away from unsustainable forms of mass tourism towards culture- and nature- based forms of tourism.

This study contains some limitations including that, notwithstanding the care taken by the authors, data gathering could not proceed parallel in China and Italy due to differences in the educational system. Moreover, the sole reliance on questionnaire survey may lead to overestimation of some of the correlations among variables due to shared method variance (Podsakoff, McKenzie, Lee, \& Podsakoff, 2003). Adding qualitative measures (e.g., in-depth interviews) would help in this direction. This study only targets university students. Although university students fall in the same age category as young travellers and have a higher chance to travel independently (a precondition for participating in this study), future research should investigate a broader representation of this generation and also be extended to other countries. Arguably, a larger sample size could have yielded a more refined picture of young Chinese travel motivations, distinguishing, for example, between a nature-related and a culture-related motivation now coalesced in the second component. Therefore, further studies are particularly encouraged in China. Finally, preferably using a semi-experimental design, future studies could examine whether specific types of sustainable tourism are of appeal to specific clusters of young travellers, and in particular, whether the segments labelled in this study as 'Junzi' and 'True eco-tourist' 
are actually attracted towards more sustainable forms of tourism than other segments. Notwithstanding these limitations, the study's results unveil at least partially the mystery surrounding young tourists.

\section{Declaration of Conflicting Interests}

The author(s) declared no potential conflicts of interest with respect to the research, authorship, and/or publication of this article.

\section{References}

Arnett, J. J. (2006). Emerging adulthood: Understanding the new way of coming of age. In Arnett, J. J., \& Tanner, J. L. (eds.) (2006), Emerging adults in America: Coming of age in the $21^{\text {st }}$ century. Washington, DC: APA, 3-19.

Benckendorff, P., \& Moscardo, G. (2010). Mythbusting: Generation Y and travel. In Benckendorff, P., Moscardo, G., \& Pendergast, D. (eds.) (2010), Tourism and Generation Y. Wallingford: CAB International, 16-26.

Bergman, S.M., Fearrington, M.E., Davenport, S.W., \& Bergman, J.Z. (2011). Millennials, narcissism, and social networking: What narcissists do on social networking sites and why. Personality and Individual Differences, 50(5), 706-711.

Beugelsdijk, S., \& Welzel, C. (2018). Dimensions and dynamics of national culture: Synthesizing Hofstede with Inglehart. Journal of Cross-Cultural Psychology, 49(10), 1469-1505.

Bonnes, M., Carrus, G., \& Passafaro, P. (2006). Psicologia ambientale, sostenibilità e comportamenti ecologici [Environmental psychology, sustainability and ecological behaviors]. Rome: Carocci Editore.

Buckley, R. (2012). Sustainable tourism: Research and reality. Annals of Tourism Research, 39(2), 528546.

CAF (Charities Aid Foundation) (2018). World Giving Index, URL: https://www.cafonline.org/docs/default-source/about-us-publications/caf_wgi2018_report_ webnopw_2379a_261018.pdf?sfvrsn=c28e9140_4 (Accessed on 19.08.2019).

Cai, H., Kwan, V.S.Y., \& Sedikides, C. (2012). A sociocultural approach to narcissism: The case of modern China. European Journal of Personality, 26(5), 529-535.

Canavan, B. (2017). Narcissism normalisation: tourism influences and sustainability implications. Journal of Sustainable Tourism, 25(9), 1322-1337.

Cavagnaro, E., \& Staffieri, S. (2015). A study of students' travellers values and needs in order to establish futures patterns and insights. The Journal of Tourism Futures, 1(2), 94-107.

Cavagnaro, E., Staffieri, S., \& Postma, A. (2018). Understanding millennials' tourism experience: values and meaning to travel as a key for identifying target clusters for youth (sustainable) tourism. The Journal of Tourism Futures, 4(1), 31-42.

Cohen, E. (1982). Marginal paradises: Bungalow tourism on the islands of Southern Thailand. Annals of Tourism Research, 9(2), 189-228.

Crocetti, E., Fermani, A. Pojaghi, B., (2009). Strategie di coping ed identità in adolescenza (Coping strategies and identity in adolescents). Età Evolutiva, 92, 45-56.

Crompton, J. L. (1979). Motivations for pleasure vacation. Annals of Tourism Research, 6(4), 408-424.

Davis, A. (2016). Experiential places or places of experience? Place identity and place attachment as mechanisms for creating festival environment. Tourism Management, 55, 49-61.

Debevec, K., Schewe, C. D., Madden, T. J., \& Diamond, W. D. (2013). Are today's Millennials splintering into a new generational cohort? Maybe! Journal of Consumer Behaviour, 12(1), 20-31.

Decataldo, A., Ruspini, E., Gilli, M., \& Del Greco, M. (2013). Turismo, generi e generazioni [Tourism, genres and generations]. Bologna: Zanichelli. 
De Groot, J. I. M., \& Steg, L. (2008). Value orientations to explain beliefs related to environmental significant behavior: How to measure egoistic, altruistic, and biospheric value orientations. Environment and Behavior, 40(3), 330-354.

Demos \& Pi (2008). XX Osservatorio sul Capitale Sociale degli Italiani, Gli Italiani e la Crisi Economica. Vicenza, Italy: Demos \& Pi. URL: http://www.demos.it/2008/pdf/capitale_sociale_20.pdf (Accessed on 19.08.2019).

Di, T. J. (2018). The value predicament and transcendence for "youth with Buddha-like calm attitude". Beijing Youth Research, 4, 16-22.

Dietz, T., Fitzgerald, A., \& Shwom, R. (2005). Environmental Values. Annual Review of Environment and Resources, 30(1), 335-372.

Dinhopl, A., \& Gretzel, U. (2016). Selfie-taking as touristic looking. Annals of Tourism Research, 57, 126139.

Doran, R., Hanss, D., \& Larsen, S. (2016). Intentions to make sustainable tourism choices: do value orientations, time perspective, and efficacy beliefs explain individual differences? Scandinavian Journal of Hospitality and Tourism, 17(3), 223-238.

Everitt, B.S., Landau, S. \& Leese, M. (2001). Cluster Analysis. 4th edn. London, England: Arnold.

Fermani, A., Crespi, I., Stara, F. (2016). Sustainable hospitality and tourism at different ages: women's and men's attitudes in Italy. Research in Hospitality Management. 6(1), 83-92.

Fodness, D. (1994). Measuring tourist motivation. Annals of Tourism Research, 21(3), 555-581.

Fu, X., Cai, L., \& Lehto, X. (2015). A Confucian Analysis of Chinese Tourists' Motivations. Journal of Travel \& Tourism Marketing, 32(3), 180-198.

Furlow, N.E. (2011). Find us on Facebook: how cause marketing has embraced social media. Journal of Marketing Development and Competitiveness, 5(6), 61-64.

Gao, J., Zhang, C., \& Huang, Z. (2018) Chinese tourists' views of nature and natural landscape interpretation: a generational perspective, Journal of Sustainable Tourism, 26(4), 668-684.

Gatti, S., \& Maroni, F. (2004). A profile of wine tourists in some Italian region vineyards: an application of the multiple correspondence analysis. Colloque Enométrie XI, Dijon: 21-22 of May. URL: https://www2.stat.unibo.it/gatti/pag_sit/Gatti-Maroni.pdf (Accessed on 05.07.2018).

Gillison, F. B., Rouse, P., Standage, M., Sebire, S. J., \& Ryan, R. M. (2019). A meta-analysis of techniques to promote motivation for health behaviour change from a self-determination theory perspective. Health Psychology Review, 13(1) 110-130.

Glover, P. (2010). Generation Y's future tourism demand: some opportunities and challenges. In Benckendorff, P., Moscardo, G., \& Pendergast, D. (eds) (2010), Tourism and Generation Y. Cambridge, MA: CAB International, 155-163.

Gong, W. J. (2008). A gender comparison on the environment-friendly behaviors of contemporary urban residents. Journal of China University of Geosciences, 8(6), 37-42.

Goossens, C. (2000). Tourism information and pleasure motivation. Annals of Tourism Research, 27(2), 301-321.

Griskevicius, V., Tybur, J. M., \& Van den Bergh, B. (2010). Going green to be seen: Status, reputation, and conspicuous conservation. Journal of Personality and Social Psychology, 98, 343-355.

Higgins-Desbiolles, F. (2006). More than an "industry": The forgotten power of tourism as a social force. Tourism Management, 27, 1192-1208.

Hindley, A., \& Font, X. (2014). Ethics and influences in tourist perceptions of climate change. Current Issues in Tourism, 20(16), 1684-1700.

Hourdequin, M., \& Wong, D.B (2005) A relational approach to environmental ethics, Journal of Chinese Philosophy, 32(1), 19-33.

Hsu, C.H.C., \& Huang, S. (2016). Reconfiguring Chinese cultural values and their tourism implications. Tourism Management, 54, 230-242. 
Huang, S., \& Hsu, C.H.C. (2005). Mainland Chinese residents' perceptions and motivations of visiting Hong Kong: Evidence from focus group interviews. Asia Pacific Journal of Tourism Research, 1o(2), 191-205.

Istituto Giuseppe Toniolo (2018). La condizione giovanile in Italia. Rapporto giovani 2018 [Youth condition in Italy. Youth report 2018]. Bologna: Il Mulino.

Ivanov, S. (2009). Ego tourism. Yearbook of International University College, Volume 4, pp.140-143.

Istat, (2015). Rapporto annuale 2015 - La situazione del Paese [Annual report 2015 - The situation in the country]. Roma: Istat.

Italian Ministry for Cultural Heritage and Activity, MiBACT (s.d.) Turismo Italia-Cina (Tourism ItalyChina). URL: http://www.turismo.beniculturali.it/attivita-internazionali/turismo-italia-cina/ (Accessed on 27.02.2019).

Jørgensen, M. T., Law, R., \& King, B. E. (2017). Understanding the past, anticipating the future - a critical assessment of China outbound tourism research. Journal of Travel E Tourism Marketing, 34(7), 880-891.

Kim, H., Borges, M. C., \& Chon, J. (2006). Impacts of environmental values on tourism motivation: The case of FICA, Brazil. Tourism Management, 27(5), 957-967.

Kim, J. H., Ritchie, J.R.B., \& McCormick, B. (2012). Development of a scale to measure memorable tourism experiences. Journal of Travel Research, 51(1), 12-25.

Kollmuss, A., \& Agyeman J. (2002) Mind the Gap: Why do people act environmentally and what are the barriers to pro-environmental behavior? Environmental Education Research, 8(3), 239-260.

Komppula, R., Honkanen, A., Rossi, S., \& Kolesnikova, N. (2018). The impact of values on sustainable behaviour - A study among Russian and Finnish university students. European Journal of Tourism Research, 19, 116-131.

Lee, S., Scott, D., \& Kim, H. (2008). Celebrity fan involvement and destination perceptions. Annals of Tourism Research, 35(3), 809-832.

Li, J. (2017). Examining college students' environmental awareness and improving ecological civilization construction. Environmental Science and Management, 42(2), 85-93.

$\mathrm{Li}, \mathrm{Q}$. Z. (2016). A comparative study of intergenerational groups of youth values under the background of networking. Zhejiang Social Sciences, 3, 74-81.

Li, J., \& Ernst, J. (2015) Exploring value orientations toward the human-nature relationship: a comparison of urban youth in Minnesota, USA and Guangdong, China, Environmental Education Research, 21(4), 556-585.

Lindberg, K. (1991). Economic Policies for Maximizing Nature Tourism's Contribution to Sustainable Development. Washington, DC: World Resour, Inst.

Lo, I. S., McKercher, B., Lo, A., Cheung, C., \& Law, R. (2011). Tourism and online photography. Tourism Management, 32(4), 725-731.

MacCannell, D. (2002). The ego factor in tourism. Journal of Consumer Research, 29(1), 146-151.

Manrai, L. A., \& Manrai, A. (2011). Hofstede's cultural dimensions and tourist behaviors: A review and conceptual framework. Journal of Economics, Finance $\mathcal{E}$ Administrative Science, 16(31), $23-48$.

Moscardo, G., Murphy, L., \& Benckendorff, P. (2011). Generation Y and travel futures. In Yeoman, I., Hsu, C., Smith, K., \& Watson, S. (eds.) (2011), Tourism and demography. Woodeaton: Goodfellow Publishers Ltd, 87-100.

Naderi, I., \& Strutton, D. (2014). Can normal narcissism be managed to promote green product purchases? Investigating a counterintuitive proposition. Journal of Applied Social Psychology, 44(5), 375-391.

National Tourism Observatory (2011). Customer Care Turisti, Rapporto Annuale (Customer Care Tourist, Annual Report). Roma, Italy: ISNART, URL: http://www.ontit.it/opencms/opencms/ont/it/focus/ focus/INDENTIKIT_DEI_GIOVANI_VIAGGIATORI_IN_ITALIA (Accessed on 04.02.2020). 
Nickerson, N. P., Black, R. J., \& McCool, S. F. (2001). Agritourism: Motivations behind Farm - Ranch Business Diversification. Journal of Travel Research, 40, 18-26.

Ooi, N., \& Laing, J. H. (2010). Backpacker tourism: Sustainable and purposeful? Investigating the overlap between backpacker tourism and volunteer tourism motivations. Journal of Sustainable Tourism, 18(2), 191-206.

Palmonari, A. (2011). Psicologia dell'adolescenza [Psychology of adolescence]. Bologna: Il Mulino.

Pascuzzo, K, Cyr, C., \& Moss, E. (2013). Longitudinal association between adolescent attachment, adult romantic attachment, and emotion regulation strategies. Attachment $\mathcal{E}$ Human Development, 15(1), 83-103.

Pearce, P.L., \& Lee, U. I. (2005). Developing the Travel Career Approach to Tourist Motivation, Journal of Travel Research, 43(3), 226-237.

Perkins, E.E., \& Brown, P.R. (2012). Environmental Values and the So-Called True Ecotourist. Journal of Travel Research, 51(6), 793-803.

Perkins, H., \& Grace, D.A. (2009). Ecotourism: Supply of nature or tourist demand? Journal of Ecotourism, 8(3), 223-236.

Podsakoff, P.M., MacKenzie, S.B., Lee, J.Y., \& Podsakoff, N.P. (2003). Common method biases in behavioral research: A critical review of the literature and recommended remedies. Journal of applied psychology, 88(5), 879-903.

Proyrungroj, R. (2020). Volunteer Tourism: Motivations of Thai Tourists and Western Tourists. European Journal of Tourism Research, 24, 2408.

Richards, G. (2015). The new global nomads: Youth travel in a globalizing world, Tourism Recreation Research, 40(3), 340-352.

Sánchez Rivero, M., Rodríguez Rangel, C., \& Andrades Caldito, L. (2016). Analysis of spa tourist motivations: a segmentation approach based on discriminant analysis. Enlightening Tourism. A Pathmaking Journal, 6(1), 19-43.

Schwartz, S. H. (1994). Are there universal aspects in the structure and contents of human values? Journal of Social Issues, 50(4), 19-45.

Simson, M. (2016). The Chinese Millennial Traveler. URL: https://apex.aero/2016/o9/20/chinesemillennial-traveler (Accessed on 03.04.2019).

Sin-wai, C., \& Pollard, D. E. (2001). An Encyclopaedia of Translation: Chinese-English, English-Chinese. Hong Kong: The Chinese University Press.

Smith, M., Deery, M., \& Puzko, L. (2010). The Role of Health, Wellness and Tourism for Destination Development. Journal of Hospitality and Tourism Management, 17(1), 94-95.

Sparks, B., \& Pan, G. W. (2009). Chinese Outbound tourists: Understanding their attitudes, constraints and use of information sources. Tourism Management, 30(4), 483-494.

Staffieri, S. (2016). L'esperienza turistica dei giovani italiani [The tourism experience of young Italians]. Collana: Studi e Ricerche, Roma: Sapienza Università Editrice.

Steg, L., Perlaviciute, G., Van der Werff, E., \& Lurvink, J. (2014). The significance of hedonic values for environmentally relevant attitudes, preferences, and actions. Environment and Behavior, 46(2), 163-192.

Stern, P. C., Dietz, T., \& Guagnano, G. A. (1995). The new Ecological paradigm in Social-psychological context. Environment and Behavior, 27(6), 723-743.

Stone, M. J., \& Petrick, J. (2013). The educational benefits of travel experiences: A literature review. Journal of Travel Research, 52(6), 731-744.

Tacq, J. (2007). Multivariate Analysis Tecniques in Social Science Research, 3rd edition, London: Sage publications.

Tao, Z. H. (2018). The logic and guiding strategy of the "Buddhist-style Youth" phenomenon in colleges and universities. Ideological \& Theoretical Education, 5, 100-103. 
Tomova, L., Majdandžić, J., Hummer, A., Windischberger, C., Heinrichs, M., \& Lamm, C. (2017). Increased neural responses to empathy for pain might explain how acute stress increases prosociality. Social cognitive and affective neuroscience, 12(3), 401-408.

Twenge, J.M., \& Foster, J.D. (2010). Birth cohort increases in narcissistic personality traits among American college students, 1982-2009. Social Psychological and Personality Science, 1(1), 99-106.

Valentine, D.B., \& Powers, T.L. (2013). Generation Y values and lifestyle segments. Journal of Consumer Marketing, 30(7), 597-606.

Vaux Halliday, S., \& Astafyeva, A. (2014). Millennial cultural consumers: Co-creating value through brand communities. Arts Marketing, 4(1-2), 119-135.

Vermeersch, L., Sanders, D., \& Willson, G. (2016). Generation Y: indigenous tourism interests and environmental values. Journal of Ecotourism, 15(2), 184-198.

Von Dawans, B., Fischbacher, U., Kirschbaum, C., Fehr, E., \& Heinrichs, M. (2012). The social dimension of stress reactivity: acute stress increases prosocial behavior in humans. Psychological science, 23(6), 651-66o.

United Nations World Tourism Organization (UNWTO). (2016). Affiliate Members Global Reports, Volume thirteen - The power of youth travel. Madrid, Spain: UNWTO.

United Nations World Tourism Organization (UNWTO). (2015). Chinese Millennial Traveller. Madrid, Spain: UNWTO.

United Nations World Tourism Organisation \& World Youth Student \& Educational Travel Confederation UNWTO \& WYSE. (2008). Youth travel matters: Understanding the Global Phenomenon of Youth Travel. Madrid, Spain: World Tourism Organisation.

Wheeller, B. (2005). Ecotourism/egotourism and development. In Hall, C.M., \& Boyd S. (eds.) (2005), Nature-based tourism in peripheral areas: development or disaster? Clevedon: Channel View Press, 263-272.

Woody, W. C. (2018). Escapism, Control, and the Discernment of Desires. Journal of Theoretical and Philosophical Psychology, 38(2), 116-119.

Yip, K.S. (2004). Taoism and its impact on mental health of the Chinese communities. International journal of social psychiatry, 50(1), 25-42.

Yousaf, A., Amin, I., Santos, C., \& Antonio, J. (2018). Tourist's motivations to travel: A theoretical perspective on the existing literature. Tourism and hospitality management, 24(1), 197-211.

Zhao, F. (2011). Interpretations of ecological thinking of Tao Yuanming and Wordsworth's poetry. Journal of Northeast Normal University, 6, 126-128.

Zhao, Y. (2017). China's Millennials Are Driving World Travel Growth. Bloomberg Business. URL: https://www.bloomberg.com/news/articles/2017-09-21/china-s-young-globetrotters-are-drivingworld-travel-gains (Accessed on 04.12.2019).

Zani, S., \& Cerioli, A. (2007). Analisi dei dati e data mining per le decisioni aziendali [Data analysis and data mining for business decisions]. Milano: Giuffré Editore.

Zografos, C., \& Allcroft, D. (2007). The environmental values of potential ecotourists: A segmentation study. Journal of Sustainable Tourism, 15(1), 44-66.

Received: 13/07/2020

Accepted: 14/11/2020

Coordinating editor: Stanislav Ivanov 